\title{
Marketing of chickpea in Amravati district
}

\author{
S.P. PICHAD AND H.J. WAGH
}

\begin{abstract}
The present study was carried out with a view to estimate the marketing cost, margins, price spread, and producer's share in consumer's rupee in selected tahsils namely, Morshi, Achalpur, Daryapur and Chandurbazar of Amravati district in the year 2009-10. In all, total 120 chickpea cultivators were selected for the study. The results revealed that, sample cultivators sold their produce mainly through three identified marketing channels i.e. channel I (Producer - Consumer), channel II (Producer - Wholesaler - Retailer Consumer) and channel III (Producer - Wholesaler - Processor - Retailer - Consumer). The per quintal total marketing cost was observed highest in channel III i.e. Rs.240.6 followed by channel II i.e. Rs. 176.3 and channel I Rs.37.05. Among various cost components, commission, transportation and market fee charges, constituted maximum share in total cost of marketing. Price spread was observed highest in channel III i.e. Rs. 581.04 per quintal. The highest producer's share in consumer's rupees was observed in channel I (producer - consumer) i.e. 98.34 per cent.
\end{abstract}

KEY WORDS : Chickpea, Channels, Marketing cost, Price spread

How to cite this paper : Pihad, S.P. and Wagh, H.J. (2014). Marketing of chickpea in Amravati district. Internat. J. Com. \& Bus. Manage, 7(2) : 256-259.

\section{MEMBERS OF THE RESEARCH FORUM}

Correspondence to:

S.P. PICHAD, Department of Agricultural Economics and Statistics, Post Graduate Institute, Dr. Panjabrao Deshmukh Krishi Vidyapeeth AKOLA (M.S.) INDIA

Email: vipsapanapichad@ rediffmail.com

Authors' affiliations:

H.J. WAGH, Department of Agricultural Economics and Statistics, Post Graduate Institute, Dr. Panjabrao Deshmukh Krishi Vidyapeeth AKOLA (M.S.) INDIA

Email: harshwagh25@yahoo.com 